\title{
HETEROGENEITY IN CYTOKINETIC, CLONOGENIC, AND RADIATION RESPONSE INDUCED BY NUTRIENT DEPRIVATION ${ }^{1}$
}

\author{
David J. Grdina 2 \\ Kenneth D. Williamson ${ }^{3}$ \\ Tod S. Johnson 3 \\ Curtis P. Sigdestad
}

2Division of Biolorical and Medical Regearch, Argonne National Sygtem Cancer Center, IL 60432 4833; The University of Texas Houston, TX 77030 . $4_{\text {Radiation Oncol Hospital and Tumor Institute, }}$ Cancer Center, Univergity tion Oncology Department, J. G. Brown Louisville, KY 40292 .

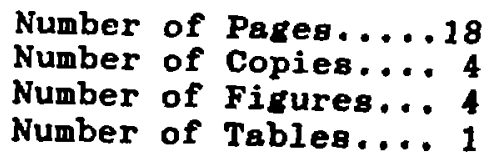

${ }^{1}$ This study was supported in part by the U.s. Department of Energy, Office of Health and Environmental Research; under contract No. W-31-109-ENG-38 and Public Health Service Grant No. CA37435 awarded (DJG) by the National Cancer Institute,
Department of Human Services. 
PROPOSED RUNNING TITLE: Heterogeneity in Radiation Response

\title{
Address Correspondence and Reprint Requests to:
}

\author{
David J. Grdina, BEM, 202 \\ Argonne National Laboratory \\ Argonne, IL 60439-4833
}

\section{DISCLAIMER}

This report was prepared as an account of work sponsored by an agency of the United States Government. Neither the United States Government nor any agency thereof, nor any of their employees, makes any warranty, express or implied, or assumes any legal liability or responsibility for the accuracy, completeness, or usefulness of any information, apparatus, product, or process disclosed, or represents that its use would not infringe privately owned rights. Reference herein to any specific commercial product, process, or service by trade name, trademark, manufacturer, or otherwise does not necessarily constitute or imply its endorsement, recommendation, or favoring by the United States Government or any agency thereof. The views and opinions of authors expressed herein do not necessarily state or reflect those of the United States Government or any agency thereof. 
Grdina, D.J., Williamson, K.D, Johnson, T.S. and Sigdestad, C.P. Heterogeneity in Cytokinetic, Clonogenic and Radiation Response Induced by Nutrient Deprivation. Radiat. Res. XXX

A murine fibrosarcoma cell Iine (FSA 1233), with a capability to grow in vitro, was used to study biophysical heterogeneity induced by nutrient deprivation. Cell sub-populations were isolated by centrifuging cells through linear Renografin-density gradients. The effects of cell growth to late plateau phase on the cytokinetic, clonogenic, and radiation-survival characteristics were studied. It was observed that with increasing age of the cell culture, an increase in the proportion of relatively dense cells was associated with a decrease in plating efficiency. Cells collected at $p=1.08 \mathrm{~g}^{\mathrm{c}} \mathrm{cm}^{3}$ have a plating efficiency of $0.2 \%$ compared with $0.01 \%$ for those isolated at $p=1.16 \mathrm{~g} / \mathrm{cm}^{3}$. Discrepancies were also seen between the tritiated thymidine labeling index (LI) and flow cytometry (FCM, $x$ s phase) for cells collected throughout the gradient. The radiation sensitivities of selected cell populations isolated by density gradient centrifugation were determined and compared with data from a control plateau phase population. Analysis of resulting survival curves indicated that cells isolated from the more dense regions of the gradient $\left(\mathrm{p}=1.15 \mathrm{~g} / \mathrm{cm}^{3}, \mathrm{D}_{\mathrm{o}}=1.40 \mathrm{~Gy}\right.$ ) exhibited a greater $\mathrm{D}_{\mathrm{o}}$ than did unseparated control cells $\left(D_{0}=0.91 \mathrm{~Gy}\right)$. In contrast to the unseparated control populations, the survival curve describing the more dense cellg lacked a significant shoulder. These findings are consistent with survival data obtained from density-separated cells $\left\langle e \cdot \mathrm{g}, \mathrm{p}=1.14 \mathrm{~g} / \mathrm{cm}^{3}\right\rangle$ directly isolated from a murine fibrosarcoma and then irradiated in vitro. 


\section{INTRODUCTION}

Solid tumors are comprised of a heterogeneous population of cells having different genetic, kinetic, and morphological features. This heterogeneity is a determinant factor in the curability of tumors by either antineoplastic drugs or radiation. An effective experimental approach to study factors affecting tumor heterogeneity has been to separate and isolate unique cell subpopulations. Several different biophysical techniques have been developed. Buoyant density banding has been previously used to resolve at least five populations of cells, based upon their buoyant densities, from disaggregated murine fibrosarcomas (FSa) $(1,2)$. Interestingly, each of the isolated tumor subpopulations contained cells exhibiting different levels of ${ }^{3} \mathrm{H}$-thymidine labeling, plating efficiencies, and radiosensitivities $(3,4)$. Generally, the relatively lighter populations $\left(p=1.05-1.08 \mathrm{~g} / \mathrm{cm}^{3}\right)$ were enriched in cells which were actively cycling, expressed higher cloning efficiency, and exhibited a relatively greater radiosensitivity. In contrast, the more dense tumor cell subpopulations $(p=1.14$ and 1.17 $\left.\mathrm{g} / \mathrm{cm}^{3}\right)$, contained noncycling cells which had reduced cloning efficiencies and were more radioresistant. These latter populations have been characterized as being chronically hypoxic using radiobiological end points $(2,5,6)$.

A variety of cultured cell aystems have been developed to serve as in vitro tumor models. Among these is the use of nutritionally deprived cell cultures grown to plateau phase. 
This procedure gives rise to the formation of populations of cells differing in density and proliferative capacity (7). In particular, this model allows for the development and characterization of highly enriched quiescent cell populations $(7,8)$. With the advent of a murine fibrosarcoma-derived clone designated FSA 1233 which is capable of growing in vitro (9), it was of interest to compare the clonogenic, lrinetic, and radiation-response properties of tumor subpopulations derived following growth in vitro to plateau phase with those populations isolated from tumors growing in vivo.

This report describes the use of FSA 1233 cells grown as unfed cultures to plateau phase as an in vitro tumor model with which to study parameters relating to tumor heterogeneity. Specifically, we have characterized the cytokinetic, clonogenic, and radiation-response properties of cell populations grown to plateau phase as unfed cultures and then separated by density gradient centrifugation.

\section{MATERIALS AND METHODS}

\section{Cells and Irradiation Conditions}

Cultures of cloned murine fibrosarcoma cells, line FSA 1233 (9), were grown in Hsu's modified McCoy's 5A media containing $20 x$ fetal calf serum (FCS) in a $5 \times \mathrm{CO}_{2}$-humidified incubator at $37^{\circ} \mathrm{C}$. Plateau phase cultures were established by plating $3.7 \times 10^{6}$ cells in $29 \mathrm{~mL}$ media into culture flasks with a growing surface area of $124 \mathrm{~cm}^{2}$. The cells were allowed to grow for seven days 
without media replacement. The $\mathrm{pH}$ of the growth media after seven days was determined and found to approximate 6.2. On day 7 , the cells were harvested by trypsinization $(0.025 \%$ trypsin $20^{\circ} \mathrm{C}, 5 \mathrm{~min}$ ) and resuspended in the original seven-day-old culture media. Each freshly harvested cell suspension was either used as a control or irradiated with a ${ }^{137} \mathrm{Cs}$ source $(1.23 \mathrm{~Gy} / \mathrm{min})$ in a $2 \mathrm{~mL}$ volume on ice.

\section{Gradient8}

Buoyant density banding of cells was carried out on sterilepreformed density gradients of Renografin-60 (methyl-glucamine $\mathrm{N}, \mathrm{N}^{1}$-diacetyl-3,5-diamino 2,4,6triiodobenzoate; E.R. Squibb \& Sons, New York, NY) as previously described (1-4). Briefly, stock solutions of 10 and $35 \%$ were made by diluting with the appropriate volumes of Ringers solution, U.S.P. (Baxter Laboratories, Division of Travenol Laboratories, Inc., Morton Grove, IL) with DNase (Deoxyribonuclease 1, crude from beef pancreas; SIGMA Chemical Co., St. Louis, MO) also present at a final concentration of $0.1 \mathrm{mg} / \mathrm{mL}$. Cells were layered onto $15 \mathrm{~mL}$ gradients and centrifuged in SW 27 tubes at 10,000 rpm (about $13,000 \mathrm{~g})$ at $4^{\circ} \mathrm{C}$ in a Beckman model L5-50 preparative ultracentrifuge for $30 \mathrm{~min}$. The initial rotor speed was set at $5000 \mathrm{rpm}$ and then accelerated each ninute by increments of 1000 rpm to the desired speed. Deceleration occurred with the brate off. Gradients were either fractionated or individual bands were removed. Fractionization was performed by removing $1 \mathrm{~mL}$ aliquots 
from the top of the gradient using a densi-flow fractionator (Buchler Inst., Division of Searle Analyiic Inc., Fort Lee, NJ). Alternatively, individual density bands were removed from the gradients by introducing a 25 gauge needle on a $3 \mathrm{~mL}$ syringe through the side of the cellulose nitrate centrifuge tube.

\section{Labeling Indices}

Plateau phase cells were labeled for $2 \mathrm{~h}$ with ${ }^{3} \mathrm{H}-\mathrm{TdR}$ (spec. act. $53 \mathrm{Ci} / \mathrm{mM}$ diluted to a final concentration of $0.1 \mathrm{uCi} / \mathrm{mL}$ of culture media). Slides were dipped in Kodak NTB2 emulsion (diluted $1: 3$ in distilled water), exposed for two weeks, developed by standard autoradiographic techniques, and stained with Giemsa May-Grunwald. Cells were counted as labeled if they contained 5 grains or more above background. A minimum of 500 cells were counted for each point.

\section{Plating Efficiency}

Aliquots of cells were washed and resuspended to fresh media. Viable cell counts for plating were performed using a hemacytometer with phase contrast microscopy. Cells were plated into $5 \mathrm{~mL}$ media in $60 \times 15 \mathrm{~mm}$ Falcon culture dishes (Becton, Dickinson \& Co., Cockeysville, MD) and colonies of 50 cells or more were counted at 14 days. 


\section{Flow Cytometric Analysig}

Samples of plateau phase FSa were harvested from either culture flasks or as $1 \mathrm{~mL}$ fractions from buoyant density gradients as described above and resuspended in McCoy's 5A media. Following pelleting, the cells were resuspended in ice-cold phosphate-buffered saline, and suspension fixed in $70 \%$ cold ethanol. After fixation for 24 hours the cells were stained with ethidium bromide and mithramycin, and at least 15,000 cells per sample analyzed. DNA fluorescence distributions were obtained using an ICP-11 Flow Cytometer as previously described (10).

\section{RESULTS}

Figure 1 (top panel) shows a representative cell density distribution profile for plateau phase FSA 1233 cells, where the cellular recovery is plotted against gradient density. Cells were distributed throughout the gradient with the majority being collected within the density range of 1.06 to $1.16 \mathrm{~g} / \mathrm{cm}^{3}$. Cells collected at densities of $1.06,1.10$ and $1.15 \mathrm{~g}^{\mathrm{cm}} \mathrm{cm}^{3}$ were routinely sampled and assayed for radiation response.

The cell cycle distribution and $3_{\mathrm{H}-\mathrm{TdR}}$ labeling index (LI) values were compared for cells having different buoyant densities. It was observed that both the $* s$ fraction (DNA distribution) and LI values for cells analyzed from the same cultures decreased with increasing buoyant density (Figure 1 , middle panel), however, the $x S$ determined as by flow cytometry was consistently higher than the corresponding values of LI. For 
example at $\mathrm{p}=1.06$ and $1.16 \mathrm{~g} / \mathrm{cm}^{3}$ the values were $51 x$ vs. $12 x$ and $10 \%$ vs. $3 \%$ for $\% S$ and $\% L I$, respectively.

Based on in vitro plating assays it was determined that the FSA cells exhibiting relatively lighter buoyant densities were, for the most part, more clonogenic than those banding at the higher buoyant densities. For example, the plating efficiency at $p=1.08$ and $1.13 \mathrm{~g} / \mathrm{cm}^{3}$ were $0.2 \%$ and $0.1 \%$, respectively, decreasing to $0.01 \%$ at $p=1.16 \mathrm{~g} / \mathrm{cm}^{3}$ (Figure 1 , bottom panel). Not shown are plating efficiencies for unseparated exponential and plateau phase cells which are $5 \%$ and $0.15 \%$, respectively.

The DNA distributions for cells from each fraction were studied and the DNA histograms are shown in Figure 2 . It is evident from these data that the lighter density cells ( $p=1.04$ to $1.08 \mathrm{~g} / \mathrm{cm}^{3}$ ) are enriched in late $S$ and $G_{2}+M$ phase cells. Cell cycle distributions indicative of late plateau populations were observed in the heavier fractions $\left(p>1.11 \mathrm{~g} / \mathrm{cm}^{3}\right)$. The survival curves for unseparated plateau phase and exponential growing cells are shown in Figure 3 . The $D_{0}$ values and associated standard errors calculated using a computer regression algorithm, are $2.18 \pm 0.26 \mathrm{~Gy}$ for the exponential and $0.91 \pm 0.11 \mathrm{~Gy}$ for the plateau phase cells, respectively. Three populations were collected following density centrifugation of plateau phase cells and their relative response to irradiation was determined. Because of the low numbers of cells recovered and/or their associated enhanced sensitivities to killing by ionizing radiation at doses greater than $4 \mathrm{~Gy}$, it was 
not possible to construct meaningful survival curves for cell populations banding at densities of 1.06 and $1.10 \mathrm{~g} / \mathrm{cm}^{3}$.

Survival data for each of the three density separated populations at radiation doses of 2 and 4 Gy are presented for comparison in Table 1. Figure 4 presents graphical data on the survival of band 3 cells $\left(p=1.15 \mathrm{~g} / \mathrm{cm}^{3}\right)$ which were shown to have a $D_{0}$ of $1.40 \mathrm{~Gy})$. Notably absent is the shoulder region of the survival curve.

\section{DISCUSSION}

FSA 1233 cells grown in vitro under conditions of nutrient deprivation to simulate an aspect of the environmental heterogeneity existent in tumors growing in vivo were investigated with respect to: buoyant density banding patterns, cytokinetics, clonogenicity and radiation response. We observed that nutrient deprivation as a result of growth to late plateau phase induced qualitatively similar density banding patterns and clonogenic characteristics as previously observed for in vivo FSa tumors (2-4). Results not presented indicate that as the age of the FSA 1233 cell cultures increases, there was an increase in the proportion of relatively dense cells which was also associated with a decreased plating efficiency. These findings are in agreement with our earlier report in which the response of CHO cells was described (7). In a previous atudy using FSa cells grown in vivo and separated on density gradients, it was demonstrated that the more dense cells $\left(p=1.14 \mathrm{~g} / \mathrm{cm}^{3}\right)$ responded as relatively resistant hypoxic cells to radiation $(1,2)$." The 
data presented here suggest that density changes can be induced by nutrient deprivation or low $\mathrm{pH}$ (approximately 6.2) and that these changes are associated with changes in radiation sensitivity and clonogenicity. Presumably, chronically hypoxic cells within a tumor also experience similar limitations in nutrient accessibility and related pH effects. Cell populations from tumors tend to show a varied and complex cell distribution pattern when centrifuged in density gradients.

Comparison of the DNA distributions obtained using flow cytometry and the percent labelled cells using $3_{\mathrm{H}-\mathrm{TdR}}$ autoradiography, indicated that the percentage of cells in $\mathrm{S}$ phase as analyzed by the former were consistently higher than were the labelling index values for corresponding cell populations. This data supports the contention that, at least under the growth conditions used, there may be cells with DNA content consistent with $S$ phase cells which are not actively synthesizing DNA or are slowly cycling. Under this latter condition, they most probably would not incorporate adequate ${ }^{3 \mathrm{H}}$ TdR during the 2 hour labeling period to be counted as labeled by autoradiography. Such discrepancies exist for populations of cells igolated from solid tumors (4). Evidence for the existence of non-cycling S-phase cells has been observed using WI-38 cells (11), $\mathrm{V}_{2}$ 79-171b and $\mathrm{MCa}-11$ spheroids (12) and diploid rat kidney cells (8). It has been reported, however, that if cell populations were separated from in vivo tumors and then grown in fresh medium prior to labeling in vitro the labeling index of 
each population corresponded well with the $X S$ as determined by FCM (4). These results suggest that under in vivo conditions, there are populations of cells sufficiently removed from the functional vasculature so as to be inaccessible to $3_{\mathrm{HTdR}}$.

Nutrient deprivation has been shown to affect radiation response in a number of different cell systems. Wallen et al., (13) have shown than well oxygenated nutrient-deprived nonproliferating plateau cells are more sensitive to radiationinduced cytotoxicity than exponentially growing cells. Data presented in figure 3 confirm these results.

The cell separation procedures used here again demonstrate that cell subpopulations differing in buoyant density, exhibit different radiation responses. Specifically, the survival curves for the heavy cells $\left(p=1.15 \mathrm{~g} / \mathrm{cm}^{3}\right)$ exhibited no shoulder region and an increased $D_{0}$ value following irradiation as compared to unseparated plateau phase cells. This same phenomena has been demonstrated in heavy banding FSa cells grown in vivo and irradiated in vitro, Under these conditions, unseparated control cells (USC) had $a \mathrm{n}$ of 3.3 and $a D_{0}$ of 1.44 Gy while band IV cells, obtained at a density of $1.137 \mathrm{~g} / \mathrm{cm}^{3}$, had a $\mathrm{n}$ of 0.8 and a $D_{0}$ of $1.93 \mathrm{~Gy}(4)$. Luk et al. (14) also demonstrated a reduction in shoulder width in quiescent subpopulations isolated from multicellular spheroids. Other investigators (15) have shown that quiescent cells, produced by nutrient deprivation, have a 2 fold increase in DNA strand breaks after irradiation as compared to proliferating cells. 
Tumor cell heterogeneity presents complexities in the study of the various factors which may limit tumor curability. Attempts to develop in vitro models such as examining the therapeutic response of late plateau phase cells, suffer from the same limitations because the growth limiting conditions induce tumor cell heterogeneity which again confounds detailed evaluation. We propose that this difficulty can be resolvea by using density gradient centrifugation, which isolates biophysically unique target cell populations which then can be studied individually and compared to the original cell population.

In summary, the application of density gradient centrifugation to the study of cellular heterogeneity induced by environmental factors in vitro or in vivo is an effective approach with which to study complex issues relating to solid tumor growth and its response to single or combined therapeutic modalities.

Work supported by the U.S. Department of Energy, Office of Health and Environmental Research under Contract No. W-31-109-ENG-38. 
TABLE 1

SURVIVING FRACTION OF DENSITY SEPARATED POPULATIONS

\begin{tabular}{lccc}
\hline & \multicolumn{3}{c}{ DENSITY $\left(\mathrm{g} / \mathrm{cm}^{3}\right)$} \\
& $p=1.06$ & $p=1.10$ & $p=1.15$ \\
\hline 2.0 & $0.389 \pm 0.101$ & $0.379 \pm 0.078$ & $0.286 \pm 0.053$ \\
4.0 & $0.017 \pm 0.012$ & $0.139 \pm 0.044$ & $0.060 \pm 0.016$ \\
\hline
\end{tabular}




\section{LEGENDS}

FIGURE 1: Salient cell separation data as a function of density obtained from Renografin gradients. (Top panel) Percentage of cells recovered. (Middle panel) Comparison of DNA distribution ( $x$ s-phase) as determined by flow cytometry and the labeling index ( $\%$ LI) as determined by ${ }^{3} \mathrm{H}-\mathrm{TdR}$ autoradiography. (Bottom panel) Clonogenicity of FSa cells grown in vivo or in vitro.

FIGURE 2: Comparison of DNA distributions obtained for plateau phase FSa cells, either unseparated control cells (USC) or separated by density gradient centrifugation through linear Renografin gradients. Each histogram represents at least 15000 cells analyzed, where at least 4000 cells were collected in the $G_{1}$ peak channel. The corresponding density $(p)$ and computer-derived $* S$ phase values are listed for each histogram.

FIGURE 3: Cell survival curves for FSa 1233 cells following exposure to ${ }^{137} \mathrm{Cs}$ gamma irradiation during either exponential $\left(D_{0}=2.18 \pm 0.2 \mathrm{~Gy}\right)$ or late plateau growth ( $D_{0}$ $=0.91 \pm 0.11 \mathrm{~Gy}$.

FIGURE 4: Radiation cell survival curve for Band 3 cells $(p=$ $1.15, D_{0}=1.4 \mathrm{~Gy}$ ) separated on Renografin density sradients. 


\section{REFERENCES}

1. Grdina, D.J., Basic, I., Mason, K.A., and Withers, R.H, Radiation response of clonogenic cell populations separated from a fibrosarcoma. Radiat. Res. 63:483-493, 1975.

2. Grdina, D.J., Basic, I., Guzino, S., Mason, K.A. Radiation response of cell populations irradiated in situ and separated from a fibrosarcoma. Radiat. Res., 66:634-643, 1976 .

3. Sigdestad, C.F. and Grdina, D.J. Density centrifugation of murine fibrosarcoma cells following in situ labeling with tritiated thymidine. Cell and Tissue Kinet. 14:489-600, 1981 .

4. Brock, W.A., Swartzendruber, D.E., and Grdina, D.J. Kinetic heterogeneity in density separated murine fibrosarcoma subpopulations. Cancer Res. 42:4999-5003, 1982.

5. Thames, H.D., Grdina, D.J. and Milas, L. Response of fibrosarcoma cell subpopulations to small doses of radiation delivered in situ. Int. J. Radiat Oncol. Biol. Phys. 9:2172201983 .

6. Grdina, D.J., Thames, H.D. and Milas, L. Tunor sensitizing effect by misonidazole in a clinically relevant radiation dose range. Int. J. Radiat. Onco. Biol. Phys. 10:379-383, 1984 .

7. Grdina, D.J., Meistrich, M.L. and Withers, H.R. Separation of clonogenic cells from stationary phase cultures by density gradient centrifugation. Expt1. Cell Res. 85:15-22, 
1974.

8. Mendelsohn, M.L.: The cell cycle in normal and abnormal tissues. In: The cell cycle in malignancy and immunity. Proc. of the 13th Annual Hanford Biology Symposium-Richland, Washington, October, 1973 .

9. Suzuki, N. and Withers, R.H.: Isolation from a murine fibrosarcoma of cell lines with enhanced plating efficiency in vitro. J. Natl. Cancer Inst. 60:179-183, 1978.

10. Barlogie, B., Spitzer, G., Hart, J.S., Johnston, D.A., Buchner, T., Schumann, J., and Drewinko, B.: DNA histogram analysis of human hemopoietic cells. Blood 48:245-258, 1976 .

11. Sklarew, R.J.: Simultaneous feulgen densitometry and autoradiographic grain counting with the Quantimet 720D image analysis system I. Estimation of nuclear DNA content in ${ }^{3} \mathrm{H}$-thymidine-labeled cells. J. Histochem Cytochem $\underline{30: 35-}$ 48,1982 .

12. Allison, D.C., Yuhas, J.M., Ridolpho, P.F., Anderson, S.L., and Johnson, T.S.: Cytophotometric measurement of cellular DNA content of ${ }^{3} \mathrm{H}$-thymidine-labeled spheroids. Cell Tissue Kinet. $16: 237-246,1983$.

13. Wallen, C.A, Ridinger, D.N. and Dethlefsen, L.A. Heterogeneity of $x$-ray cytotoxicity in proliferating and quiescent murine mammary carcinoma cells. Cancer Res. 45:3064-3069, 1985 .

14. Luk, C.K., Keng, P.C. and Sutherland, R.M. Radiation 
response of proliferating and quiescent subpopulations

isolated from multicellular spheroids. Br. J. Cancer $\underline{54: 25-}$ 32,1986 .

15. Waters, R.L., Lyons, B.W. Ridinger, D.N. and Dethlefsen, L.A. DNA damage repair in quiescent murine mammary carcinoma cells in culture. Biochimica et Biophysica Acta 824:357-364, 1985 . 
Fi) 1

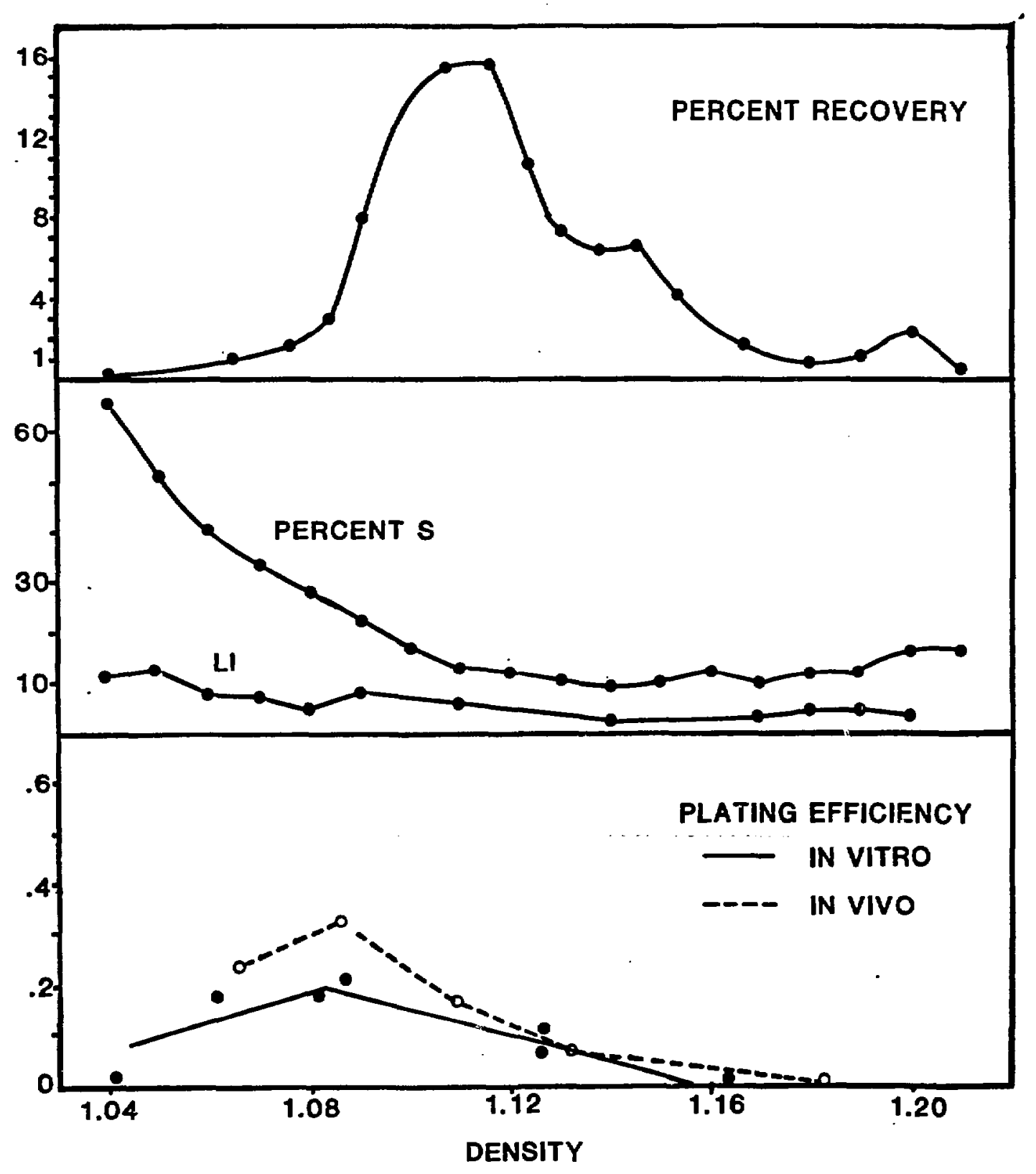


$\mathrm{Fig} 2$

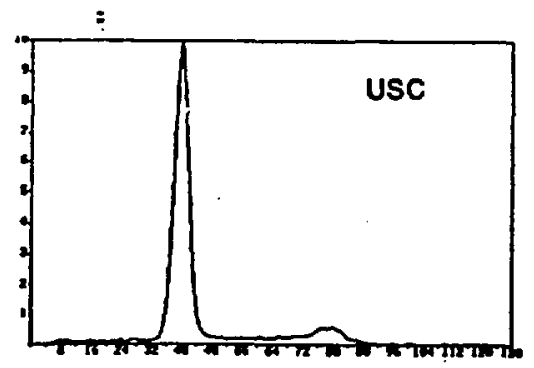

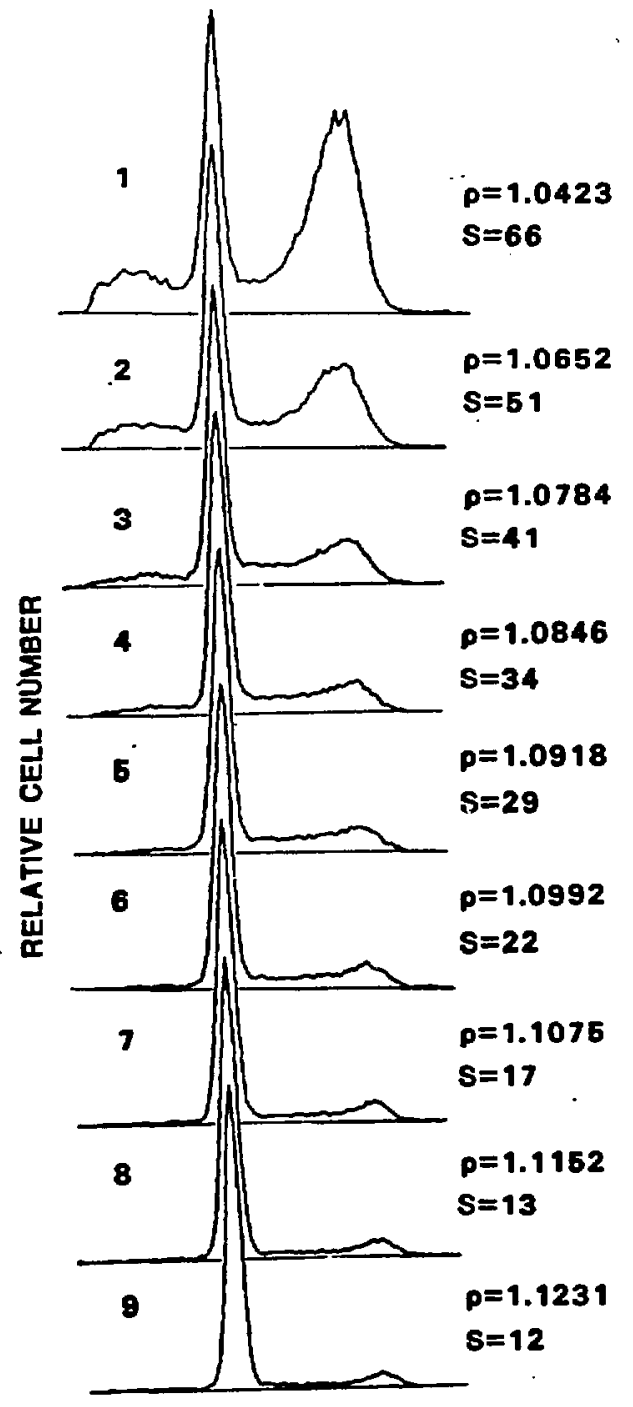

DNA CONTENT

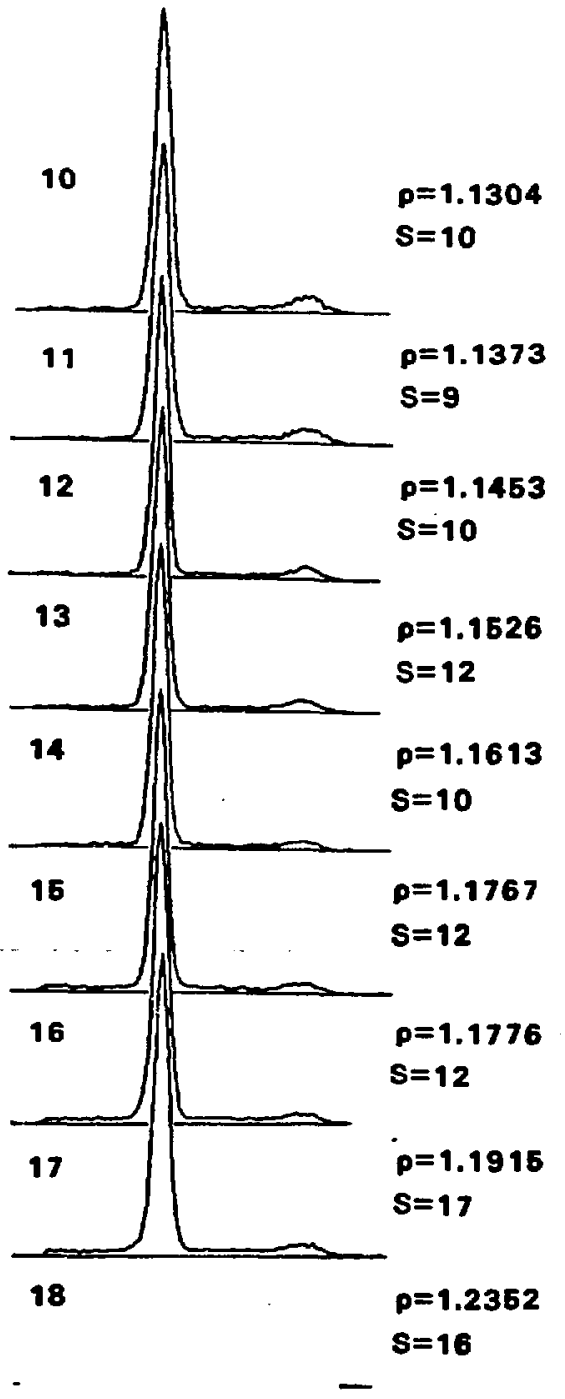

DNA CONTENT 
Fi, 3
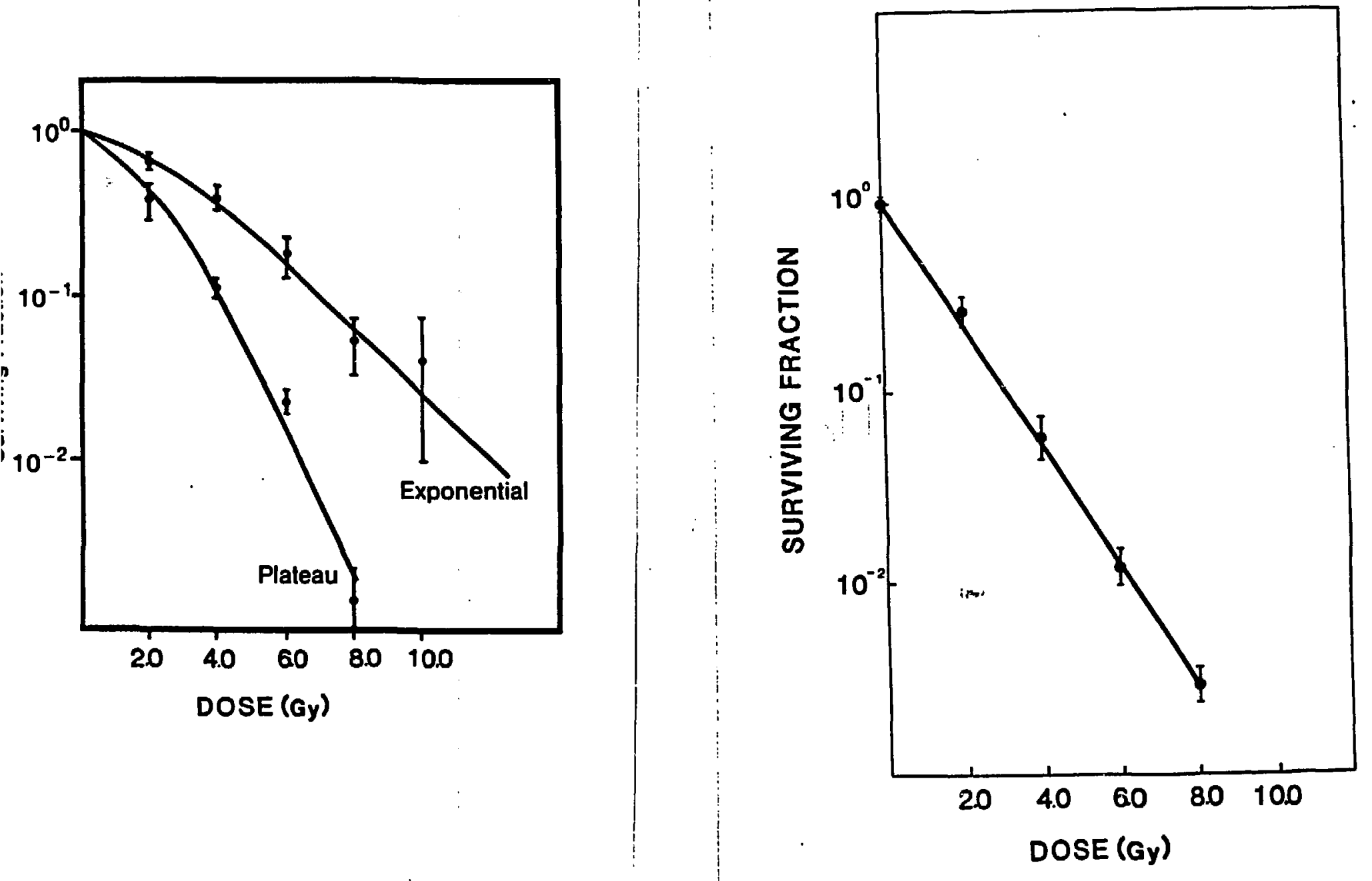